\title{
PENINGKATAN KETERAMPILAN PROSES DAN HASIL BELAJAR TEMA LINGKUNGAN SAHABAT KITA MENGGGUNAKAN MODEL PROJECT BASED LEARNING PADA SISWA KELAS 5 SD
}

\author{
Dyah Kartika Sari', Henny Dewi Koeswati2 ${ }^{2}$ Sri Giarti ${ }^{3}$ \\ 1Pendidikan Guru Sekolah Dasar, Universitas Kristen Satya Wacana 292014115@student.uksw.edu, \\ 2Pendidikan Guru Sekolah Dasar, Universitas Kristen Satya Wacana dewi@staff.uksw.edu \\ 3Pendidikan Guru Sekolah Dasar, Universitas Kristen Satya Wacana sgiarty@gmail.com
}

\section{INFO ARTIKEL}

Riwayat Artikel:

Diterima: 28-03-2018

Disetujui: 10-04-2018

\section{Kata Kunci:}

Project Based Learning Keterampilan Proses Hasil Belajar

\section{ABSTRAK}

Abstrak: Jenis penelitian ini adalah penelitian tindakan kelas. Tujuan dari penelitian ini untuk meningkatkan keterampilan proses dan hasil belajar siswa dalam pembelajaran Tema Lingkungan Sahabat Kita dengan menggunakan model Project Based Learning. Hasil penelitian menunjukkan bahwa model Project Based Learning dapat meningkatkan keterampilan proses dan hasil belajar siswa. Persentase kenaikan keterampilan proses pada siklus I sebesar $44,7 \%$ dan meningkat di siklus II menjadi 76,8\%. Ketercapaian ketuntasan hasil belajar siswa pada pra siklus adalah 28,6\%, meningkat di siklus I menjadi 53,6\%, kembali mengalami peningkatan di siklus II menjadi 85,7\%.

\begin{abstract}
This type of research was the classroom action research. The aims of the research were to improve the process skills and learning outcomes of the students in Lingkungan Sahabat Kita Theme by applaying Project Based Learning model. The research showed that by applying Project Based Learning model can improve the process skills and learning outcomes of the students. Precentage increase in process skill in cycle I was $44,7 \%$, and increased in cycle // $76,8 \%$. The achievement of students learning completeness at pre-cycle was $28,6 \%$, increasing in cycle I to $53,6 \%$, increasing again in cycle I/ to $85,7 \%$.
\end{abstract}

\section{A. LATAR BELAKANG}

Pendidikan pada hakekatnya adalah pengembangan potensi atau kemampuan manusia secara menyeluruh yang pelaksanaannya dilakukan dengan cara mengajarkan berbagai pengetahuan dan kecakapan yang dibutuhkan oleh manusia itu sendiri (Muhibbin, 2010: 32). Sehingga keberhasilan pendidikan itu sendiri tergantung pada proses pelaksanaannya atau yang bisa disebut proses pembelajaran. Dalam mencapai keberhasilan pendidikan, pemerintah menerapkan Kurikulum 2013 di semua jenjang pendidikan sekolah dasar. Oleh karena itu, proses pembelajaran dalam Kurikulum 2013 harus menampakkan proses pembelajaran yang memungkinkan siswa berlatih mengembangkan keterampilan prosesnya, yang akan berdampak pada meningkatnya hasil belajar.

Menurut Wahyudi dan Kriswadani (2010: 53) keterampilan proses merupakan kegiatan belajar mengajar yang berfokus pada penelitian siswa secara aktif dan kreatif dalam memperoleh hasil belajar. Hasil belajar yg diperoleh siswa tidak terbatas pada aspek pengetahuan saja melainkan bagaimana proses mencapai tujuan pembelajaran yang diharapkan dapat terpenuhi. Sehingga dalam proses pembelajarannya sudah tidak menerapkan teacher center tetapi lebih menerapkan student center. Namun guru juga mempunyai peran penting dalam penyampaian materi pembelajaran tematik karena guru haru memacu siswa untuk aktif berfikir terkait dengan materi serta menciptakan suatu pembelajaran yang bermakna agar siswa mampu merumuskan masalah (dengan banyak menanya), bukan hanya menyelesaikan masalah dengan menjawab saja serta diarahkan untuk melatih berpikir analitis (siswa diajarkan bagaimana mengambil keputusan) bukan berpikir mekanistis (rutin dengan hanya mendengarkan dan menghapal saja). Umi Faizah (2015: 29) mengatakan bahwa "keterampilan proses dengan pendekatan saintifik memberikan kesempatan kepada setiap siswa untuk menemukan dan mengkonstruksi sendiri pemahaman ide dan konsep pembelajaran tematik".

Berdasarkan pendapat di atas maka dapat disimpulkan bahwa keterampilan proses merupakan kegiatan belajar mengajar yang berfokus pada penelitian siswa secara aktif dan kreatif sehingga siswa dapat menemukan dan mengkontruksi sendiri pemahaman ide dan konsep pembelajaran tematik. Tantangan bagi guru SD dalam pembelajaran tematik adalah seberapa tinggi siswa mampu menguasai aspek pengetahuan, sikap dan keterampilan dan konsisten dalam memilih model pembelajaran yang tepat. Apabila tantangan ini dijawab dengan tepat, maka dimensi-dimensi pembelajaran tematik, yaitu 
keterampilan proses pembelajaran tematik dan hasil belajar siswa dapat ditingkatkan

Dalam keterampilan proses, indikator yang dikembangkan untuk siswa SD adalah aspek yang sejalan dengan pendekatan saintifik. Terdapat 5 indikator keterampilan proses sebagai fokus dari penelitian yang dilakukan. Ke-5 indikator tersebut yaitu: 1) Mengamati/ Observasi; 2) Menanya; 3) Mencoba/Mengumpulkan informasi; 4) Menalar/ Menganalisis/ Menyimpulkan; 5) Mengkomunikasikan. Apabila keterampilan proses siswa tersebut rendah akhirnya berdampak juga pada hasil belajar siswa.

Hasil belajar siswa menurut Sudjana (2011: 3) adalah perubahan tingkah laku, tingkah laku sebagai hasil belajar dalam pengertian yang luas mencakup bidang kognitif, afektif, dan psikomotoris. Tidak jauh berbeda dengan Sudjana, Rumini (2016: 23) menyatakan bahwa hasil belajar adalah total skor dari aspek kognitif, afektif dan psikomotor yang dicapai melalui proses belajar. Sehingga penilaian hasil belajar penting dilakukan karena sebagai alat untuk mengetahui tercapai atau tidaknya tujuan pembelajaran, umpan balik bagi perbaikan proses pembelajaran serta dasar dalam menyusun laporan kemajuan belajar siswa kepada para orang tuanya. Pencapaian hasil belajar diukur dengan tugas-tugas yang harus dijawab atau diselesaikan oleh siswa dengan tujuan untuk mengukur kemajuan belajar dengan tes dalam bentuk nilai.

Hasil dari observasi awal yang dilakukan menunjukkan bahwa proses pembelajaran pada pembelajaran tematik belum optimal. Hal ini ditunjukkan pada proses pembelajaran, guru secara konvensional cenderung menggunakan model pembelajaran yang menerapkan ceramah sebagai inti pembelajaran (teacher center). Dampaknya terlihat pada siswa yang menjadi kurang berminat pada pembelajaran dan mereka cepat bosan ketika di dalam kelas. Kurang minatnya siswa menjadikan mereka menjadi pasif selama pembelajaran berlangsung. Akhirnya berdampak pada rendahnya keterampilan proses siswa.

Diketahui bahwa kriteria keberhasilan keterampilan proses yaitu persentase pencapaian sebesar $80 \%$ atau skor minimal baik. Hasil observasi yang dilakukan di kelas 5 salah satu sekolah dasar di Kecamatan Purwodadi Kabupaten Grobogan pada pembelajaran Tema 2 Subtema 3 Memelihara Kesehatan Organ Pernapasan Manusia menunjukkan bahwa dari 28 siswa terdapat $8(28,6 \%)$ siswa yang memenuhi skor baik, sedangkan $20(71,4 \%)$ siswa masih belum memenuhi kriteria skor minimal baik. Hal ini menunjukkan setengah dari jumlah seluruh siswa kelas 5 masih kurang dalam keterampilan prosesnya. Karena kurangnya keterampilan proses tersebut akhirnya berdampak pada hasil belajar siswa.
Diketahui bahwa kriteria ketuntasan minimal (KKM) pada pembelajaran tematik kelas 5 SD tersebut adalah $\geq 75$. Hasil ulangan tengah semester pembelajaran tematik kelas 5 SD yang bersangkutan, semester I tahun pelajaran 2017/2018 menunjukkan bahwa dari 28 siswa terdapat $8(28,6 \%)$ siswa yang sudah mencapai KKM, sedangkan $20(71,4 \%)$ siswa belum mencapai KKM. Dengan rentang nilai tertinggi 85 dan nilai terendah 35 .

Melihat kondisi dan situasi yang terjadi pada pembelajaran di kelas $5 \mathrm{SD}$, perlu adanya perbaikan dalam proses pembelajarannya. Peneliti merasa perlu menggunakan suatu model pembelajaran yang mampu untuk meningkatkan hasil belajar serta keterampilan proses siswa terhadap materi yang dipelajarinya. Maka peneliti menyajikan model Project Based Learning sebagai salah satu model yang dapat digunakan dalam pembelajaran tematik di SD. Implementasi model Project Based Learning, secara teoritik dapat meningkatkan kompetensi keterampilan proses tematik para siswa yang nantinya akan berdampak pada peningkatan hasil belajar siswa.

Model Project Based Learning merupakan suatu model pembelajaran yang menggunakan proyek/kegiatan sebagai inti pembelajaran. Dimana peserta didik bersama dengan kelompoknya merancang, melakukan pemecahan masalah, melaksanakan pengambilan keputusan dan kegiatan penyelidikan sendiri (Warsono \& Hariyanto, 2013: 153). Hasil akhir dari model pembelajaran tersebut adalah suatu produk yang antara lain berupa laporan tertulis atau lisan, atau presentasi. Dengan model tersebut pembelajaran pun akan lebih bermakna bagi siswa karena siswa bisa untuk memecahkan permasalahan-permasalahan yang dihadapinya.

Adapun sintaks atau langkah-langkah pembelajaran dalam Project Based Learning terdiri dari: 1) Menentukan proyek; 2) Merencanakan proyek; 3) Menyusun jadwal aktivitas; 4) Mengawasi jalannya proyek (monitoring); 5) Penilaian terhadap hasil proyek; 6) Evaluasi (Sabar Nurohman, 2007: 10). Model Project Based Learning digunakan untuk melibatkan peserta didik pada obyek nyata secara optimal dalam proses pembelajaran. Keterlibatan fisik, pikiran dan mental peserta ini akan mampu mendorong motivasi belajar, keterampilan mengambil keputusan, dan melatih berpikir kritis dan kerja inovatif dalam memecahkan berbagai masalah yang dihadapi. Berdasarkan uraian tersebut, maka yang menjadi fokus dalam penelitian ini adalah apakah penerapan model Project Based Learning dapat meningkatkan keterampilan proses dan hasil belajar Tema Lingkungan Sahabat Kita pada siswa kelas 5 SD? 


\section{B. METODE PENELITIAN}

Jenis penelitian ini menggunakan penelitian tindakan kelas (PTK) karena peneliti bertindak secara langsung dalam penelitian, mulai dari awal sampai akhir tindakan. Penelitian tindakan kelas merupakan suatu upaya untuk mencermati kegiatan belajar sekelompok peserta didik dengan memberikan sebuah tindakan yang sengaja dimunculkan (Mulyasa, 2009: 11). Dengan demikian tindakan tersebut dilakukan oleh guru, oleh guru bersama peserta didik, atau oleh peserta didik dibawah bimbingan dan arahan guru dengan maksud untuk memperbaiki dan meningkatkan kualitas pembelajaran. Penelitian ini direncanakan akan dilaksanakan dalam dua siklus yang dipergunakan dengan prosedur penelitian tindakan kelas yang digunakan menurut Kemmis \& Mc Taggart dalam Arikunto (2010: 16) terdapat empat tahap rencana tindakan, meliputi: perencanaan, pelaksanaan tindakan, pengamatan/observasi, dan refleksi. Setiap siklus dalam penelitian ini terdiri dari 6 pertemuan dengan penyampaian materi melalui penerapan model Project Based Learning dengan masing-masing pertemuan berlangsung selama 8x35 menit, kemudian pada akhir pembelajaran pertemuan keenam dilakukan evaluasi. Penelitian ini dilakukan di salah satu sekolah dasar negeri di Kecamatan Purwodadi Kabupaten Grobogan pada kelas 5 yang berjumlah 28 siswa.

Data dalam penelitian ini berupa data kualitatif dan data kuantitatif. Data kualitatif berupa data yang diperoleh dari hasil observasi untuk mengetahui peningkatan keterampilan proses siswa dalam mengikuti pembelajaran yang sudah menerapkan Project Based Learning menggunakan rubrik keterampilan proses yang berisi tentang indikatorindikator keterampilan proses itu sendiri. Data kuantitatif berupa hasil belajar siswa yang diperoleh melalui tes evaluasi yang diberikan di setiap akhir siklus. Selanjutkan dilakukan komparasi data setiap siklus untuk memastikan ada tidaknya peningkatan hasil belajar siswa, peningkatan keterampilan proses.

Kriteria untuk mengukur tingkat keberhasilan upaya peningkatan pembelajaran pada penelitian ini adalah sebagai berikut:

1. Hasil belajar siswa dikatakan berhasil apabila 80\% dari 28 siswa telah berhasil mencapai standar Kriteria Ketuntasan Minimal (KKM). KKM yang diterapkan pada pembelajaran tematik adalah $\geq 75$.

2. Keterampilan proses dikatakan berhasil apabila 80\% dari 28 siswa telah mencapai skor minimal baik. Sehingga meningkatnya keterampilan proses siswa minimal sebesar 20\% untuk setiap siklusnya.

\section{HASIL}

Kegiatan perencanaan dalam siklus I dan II dilakukan mulai dari menyusun Rencana Pelaksanaan Pembelajaran (RPP) sampai dengan menyusun lembar observasi dan soal evaluasi. Selanjutnya pelaksanaan penelitian dilakukan sesuai dengan rencana awal yaitu dalam satu siklus terdiri dari enam kali pertemuan dengan masing-masing pertemuan berlangsung selama $8 \times 35$ menit, kemudain pada akhir pembelajaran pertemuan keenam dilakukan evaluasi.

Kegiatan awal dilakukan dengan mempersiapkan siswa secara fisik dan psikis, berdoa, melakukan presensi, apersepsi dan menyampaikan tujuan pembelajaran. Kegiatan inti dilakukan sesuai dengan sintaks dari model Project Based Learning. Kegiatan inti yang dilakukan dengan menerapkan model Project Based Learning dimulai dengan memberikan contoh gambar yang ditampilkan melalui PPT untuk menimbulkan suatu pertanyaan dalam pikiran siswa atau guru dapat memberikan permasalahan/topik yang nantinya siswa akan diminta untuk menyelesaikan permasalahan/topik tersebut dengan memuat indikator mengamati/observasi, kemudian dilanjutkan dengan bertanya jawab terkait dengan gambar yang ditampilkan atau permasalahan yang sedang dibahas, membagi siswa menjadi beberapa kelompok untuk melakukan kegiatan percobaan dan diskusi kelompok, menyampaikan hasil dari diskusi kelompok, guru membimbing siswa untuk menarik kesimpulan. Kegiatan akhir dilakukan dengan melakukan evaluasi pembelajaran, menarik kesimpulan dan doa penutup. Observasi dilakukan untuk memperoleh data terkait keterampilan proses siswa selama proses pembelajaran berlangsung. Selanjutnya refleksi adalah untuk mengetahui kekurangan-kekurangan yang ada pada kegiatan pembelajaran yang telah dilakukan untuk selanjutnya dilakukan perbaikan.

Hasil dari observasi keterampilan proses tiap pertemuannya pada siklus I dan II dengan menerapkan model Project Based Learning dijabarkan secara lebih jelas dalam Tabel 1 dan Tabel 2.

TABEL 1

HASIL OBSERVASI KETERAMPILAN PROSES SIKLUS I

\begin{tabular}{|c|c|c|c|c|}
\hline No & $\begin{array}{c}\text { Pertemuan } \\
\text { Ke- }\end{array}$ & $\mathbf{f}$ & $\begin{array}{l}\text { Persentase } \\
\text { Pencapaian }\end{array}$ & $\begin{array}{c}\text { Peningka } \\
\text { tan }\end{array}$ \\
\hline 1. & Pertemuan 1 & 9 & $28,6 \%$ & - \\
\hline 2. & Pertemuan 2 & 10 & $35,7 \%$ & $7,1 \%$ \\
\hline 3. & Pertemuan 3 & 12 & $42,8 \%$ & $7,1 \%$ \\
\hline 4. & Pertemuan 4 & 13 & $46,3 \%$ & $3,5 \%$ \\
\hline 5. & Pertemuan 5 & 15 & $53,5 \%$ & $7,2 \%$ \\
\hline 6. & Pertemuan 6 & 17 & $60,2 \%$ & $6,7 \%$ \\
\hline & Rata-rata & & \multicolumn{2}{|c|}{$44,67 \%$} \\
\hline
\end{tabular}

Berdasarkan Tabel 1 dapat diketahui bahwa skor keterampilan proses siswa mengalami peningkatan dari siklus I pertemuan pertama sebesar $28,6 \%$ dan pada pertemuan kedua menjadi 35,7\% dengan kenaikan sebesar $7,1 \%$. Pada pertemuan kedua juga mengalami 
peningkatan sebesar 35,7\% dan pada pertemuan ketiga menjadi 42,8\% dengan kenaikan sebesar 7,1\%. Pada pertemuan ketiga juga mengalami peningkatan dari 42,8\% dan pada pertemuan keempat menjadi 46,3\% dengan kenaikan sebesar 3,5\%. Pada pertemuan keempat juga mengalami peningkatan dari $46,3 \%$ dan pada pertemuan kelima menjadi 53,5\% dengan kenaikan sebesar $7,2 \%$. Pada pertemuan kelima juga mengalami peningkatan dari 53,5\% dan pada pertemuan keenam menjadi 60,2\% dengan kenaikan sebesar 6,7\%.

Penelitian pada Siklus I ini dikatakan belum berhasil karena belum memenuhi kriteria keberhasilan keterampilan proses yaitu persentase pencapaian sebesar $80 \%$. Oleh karena itu dilakukan tindakan kembali untuk perbaikan pada Siklus II. Berikut disajikan hasil persentase peningkatan keterampilan proses siswa selama penelitian siklus I pada Tabel 2.

TABEL 2

HASIL OBSERVASI KETERAMPILAN PROSES SIKLUS II

\begin{tabular}{ccccc}
\hline No & $\begin{array}{c}\text { Pertemuan } \\
\text { Ke- }\end{array}$ & f & $\begin{array}{c}\text { Persentase } \\
\text { Pencapaian }\end{array}$ & $\begin{array}{c}\text { Peningkat } \\
\text { an }\end{array}$ \\
\hline 1. & Pertemuan 1 & 17 & $60,7 \%$ & - \\
2. & Pertemuan 2 & 18 & $64,2 \%$ & $3,5 \%$ \\
3. & Pertemuan 3 & 21 & $75 \%$ & $10,8 \%$ \\
4. & Pertemuan 4 & 23 & $82,1 \%$ & $7,1 \%$ \\
5. & Pertemuan 5 & 24 & $85,7 \%$ & $3,6 \%$ \\
6. & Pertemuan 6 & 26 & $92,8 \%$ & $7,1 \%$ \\
\multicolumn{4}{c}{ Rata-rata } & \multicolumn{3}{c}{$76,83 \%$} \\
\hline
\end{tabular}

Berdasarkan Tabel 2 dapat diketahui bahwa skor keterampilan proses siswa mengalami peningkatan dari siklus II pertemuan pertama sebesar $60,7 \%$ dan pada pertemuan kedua menjadi 64,2\% dengan kenaikan sebesar 3,5\%. Pada pertemuan kedua juga mengalami peningkatan sebesar $64,2 \%$ dan pada pertemuan ketiga menjadi $75 \%$ dengan kenaikan sebesar $10,8 \%$. Pada pertemuan ketiga juga mengalami peningkatan dari $75 \%$ dan pada pertemuan keempat menjadi $82,1 \%$ dengan kenaikan sebesar $7,1 \%$. Pada pertemuan keempat juga mengalami peningkatan dari $82,1 \%$ dan pada pertemuan kelima menjadi $85,7 \%$ dengan kenaikan sebesar 3,6\%. Pada pertemuan kelima juga mengalami peningkatan dari $85,7 \%$ dan pada pertemuan keenam menjadi 92,8\% dengan kenaikan sebesar 7,1\%.

Setelah melakukan analisa terhadap data yang diperoleh dari dua siklus yang dilaksanakan, maka dapat disimpulkan bahwa penggunaan model pembelajaran Project Based Learning pada Tema Lingkungan Sahabat Kita menunjukkan peningkatan keterampilan proses dan ketuntasan hasil belajar siswa. Tabel 3 merangkum perbandingan hasil observasi keterampilan proses dari pra siklus, siklus I, dan siklus II:
TABEL 3

PERBANDINGAN HASIL KETERAMPILAN PROSES SISWA PADA PRA SIKLUS, SIKLUS I DAN SIKLUS II

\begin{tabular}{ccc}
\hline Pembelajaran & \multicolumn{2}{c}{ Tingkat } \\
\cline { 2 - 3 } & Mean & Kenaikan (\%) \\
Pra Siklus & 28,6 & - \\
Siklus I & 44,7 & 16,1 \\
Siklus II & 76,8 & 32,1 \\
\hline
\end{tabular}

Dari data dalam Tabel 3 diatas, diperoleh temuan: a) pada pra siklus, rata-rata tingkat keterampilan proses siswa baru mencapai 28,6; b) pada siklus I, ratarata tingkat keterampilan proses siswa mencapai 44,7. Capaian ini menunjukkan peningkatan keterampilan sebesar 16,1\%, karena kriteria peningkatan keterampilan proses harus meningkat minimal 20\% ternyata capaian pada siklus I masih belum memenuhi kriteria sehingga dilakukan tindakan siklus II; c) pada siklus II, rata-rata keterampilan proses mencapai 76,8. Data ini menunjukkan peningkatan keterampilan proses sebesar 32,1\%. Perbandingan tingkat pencapaian hasil belajar pada Tema Lingkungan Sahabat Kita dapat dijelaskan pada Tabel 4:

TABEL 4

PERBANDINGAN HASIL BELAJAR SISWA TEMA

LINGKUNGAN SAHABAT KITA PADA PRA SIKLUS, SIKLUS I DAN SIKLUS II

\begin{tabular}{|c|c|c|c|c|c|c|}
\hline \multirow{2}{*}{ Keterangan } & \multicolumn{2}{|c|}{ Pra Siklus } & \multicolumn{2}{|c|}{ Siklus I } & \multicolumn{2}{|c|}{ Siklus II } \\
\hline & $\mathbf{f}$ & $\%$ & $\mathbf{f}$ & $\%$ & $\mathbf{f}$ & $\%$ \\
\hline Tuntas & 8 & 28,6 & 15 & 53,6 & 24 & 85,7 \\
\hline Tidak Tuntas & 20 & 71,4 & 12 & 42,9 & 4 & 14,3 \\
\hline Jumlah & 28 & $100 \%$ & 28 & $100 \%$ & 28 & $100 \%$ \\
\hline Rata-Rata & \multicolumn{2}{|r|}{65} & \multicolumn{2}{|c|}{71.6} & \multicolumn{2}{|c|}{80.9} \\
\hline Nilai Tertinggi & \multicolumn{2}{|c|}{85} & \multicolumn{2}{|c|}{90} & \multicolumn{2}{|c|}{95} \\
\hline Nilai Terendah & \multicolumn{2}{|c|}{35} & \multicolumn{2}{|c|}{50} & \multicolumn{2}{|c|}{55} \\
\hline
\end{tabular}

Dari Tabel 4 dapat dijelaskan bahwa tingkat ketuntasan belajar siswa dari pra siklus sampai ke siklus II mengalami peningkatan. Pada pra siklus siswa yang tuntas belajar adalah 8 siswa $(28,6 \%)$, pada siklus I menjadi 15 siswa $(53,6 \%)$ dan pada siklus II menjadi 24 siswa (85,7\%). Sedangkan siswa yang belum tuntas jumlahnya menurun. Pada saat pra siklus terdapat 20 siswa $(71,4 \%)$ belum tuntas, pada siklus I masih 12 siswa $(42,9 \%)$ yang belum tuntas dan pada siklus II masih 4 siswa (14,3\%). Nilai tertinggi siswa meningkat yaitu pada pra siklus 85 , siklus I meningkat menjadi 90 dan pada siklus II nilai tertinggi yaitu 95. Nilai terendah pra siklus 35, siklus I menjadi 50 dan siklus II nilai terendah 55 . Rata-rata siswa dari pra siklus ke siklus II juga mengalami peningkatan dari prasiklus 65 menjadi 71,6 ke siklus I atau naik sebesar 6,6 dan pada siklus II menjadi 80,9 atau naik sebesar 9,3.

\section{PEMBAHASAN}

Berdasarkan data hasil dari penelitian, dapat diketahui bahwa pelaksanaan pembelajaran Tema Lingkungan Sahabat Kita dengan menerapkan model 
pembelajaran Project Based Learning mampu untuk meningkatkan keterampilan proses siswa sehingga juga berdampak pada meningkatnya hasil belajar siswa. Sintaks dari model pembelajaran Project Based Learning terbukti mampu meningkatkan keterampilan proses siswa, sintaks tersebut meliputi: 1) Menentukan proyek; 2) Merencanakan proyek; 3) Menyusun jadwal aktivitas; 4) Mengawasi jalannya proyek (monitoring); 5) Penilaian terhadap hasil proyek; 6) Evaluasi. Hal ini dibuktikan sesuai dengan Tabel 1.1 dimana komparasi rerata keterampilan proses pada kondisi awal sebesar 28,6, pada siklus I sebesar 44,7 dan siklus II sebesar 76,8 . Temuan ini mengindikasi adanya peningkatan pada keterampilan proses. Besaran peningkatan 16,1\% untuk siklus I dan 32,1\% untuk siklus II. Jika dibandingkan dibandingkan dengan indikator kinerja 20\% maka temuan tersebut telah mencapai keberhasilan sesuai dengan harapan peneliti.

Keberhasilan penelitian ini bermakna bahwa siswa mampu mengamati, menanya, mencoba, menalar, dan mengkomunikasikan. Hasil Temuan ini pun sejalan dengan penelitian Umi Faizah (2015) dan Ratna Malawati (2016), yang meneliti tentang pengaruh model pembelajaran Project Based Learning terhadap keterampilan proses. Hasil dari penelitian yang dilakukan menunjukkan bahwa ada keterkaitan antara penerapan Project Based Learning dengan keterampilan proses siswa serta hasil penelitiannya menunjukkan peningkatan.

Terjadinya peningkatan keterampilan proses ini juga berdampak pada peningkatan hasil belajar siswa dari siklus I ke siklus II. Ketuntasan hasil belajar siswa sebelum adanya tindakan atau pra siklus sebesar 28,6\% kemudian meningkat sebanyak $25 \%$ ke siklus I menjadi $53,6 \%$, kemudian dari siklus I ke siklus II ketuntasan hasil belajar siswa meningkat sebanyak 32,1\% sehingga menjadi $85,7 \%$. Jika dibandingkan dengan indikator kinerja $80 \%$ untuk setiap siklusnya ternyata temuan siklus I belum memenuhi indikator kinerja maka dilakukan tindakan kembali pada siklus II dan pada siklus II ketuntasan hasil belajar siswa sudah mencapai keberhasilan. Hasil temuan ini pun sejalan dengan penelitian Umi Faizah (2015) dan Ratna Malawati (2016), bahwa dengan meningkatnya keterampilan proses juga akan berpengaruh pada peningkatan hasil belajar.

\section{E. SIMPULAN DAN SARAN}

Berdasarkan hasil tindakan yang telah dilakukan oleh peneliti, maka dapat disimpulkan bahwa penerapan model Project Based Learning dapat meningkatkan keterampilan proses siswa. Peningkatan keterampilan proses siswa pada penelitian ini ditunjukkan dengan meningkatnya skor keterampilan proses siswa dari siklus I sampai siklus II. Peningkatan keterampilan proses siswa pun berdampak juga pada hasil belajarnya. Hasil belajat siswa pada pembelajaran
Tema Lingkungan Sahabat Kita dengan menerapkan model Project Based Learning meningkat secara signifikan. Peningkatan ini dapat dilihat mulai dari pra siklus, siklus I hingga siklus II yang ditunjukkan dengan persentase ketuntasan yang terus meningkat dalam setiap siklusnya.

Sehubungan dengan hasil dari penelitian tindakan kelas yang dilakukan peneliti memberikan saran dalam pelaksanaan proses pembelajaran antara lain: 1) bagi guru, pelaksanaan kegiatan pembelajaran dengan menerapkan model Project Based Learning dapat dijadikan sebagai salah satu alternatif untuk dapat meningkatkan keterampilan proses dan hasil belajar siswa, 2) keterampilan proses menjadi penting bagi siswa karena mempunyai dampak besar pada hasil belajar siswa, 3) sekolah dapat memberikan dukungan dalam pemilihan metode pembelajaran untuk perbaikan pembelajaran terkait penerapan Project Based Learning dan sekolah lebih memahami tentang pentingnya pemilihan model yang tepat untuk meningkatkan hasil belajar siswa.

\section{UCAPAN TERIMA KASIH}

Penulis mengucapkan terimakasih kepada Ibu Dr. Henny Dewi Koeswati, S.Pd., M.Pd selaku Pembimbing 1 dan Ibu Sri Giarti, S.Pd., M.Pd selaku Pembimbing 2 yang senantiasa memberikan bimbingan, nasehat, motivasi dan tempat ngeluh tiap kesulitan ngerjain kepada penulis sehingga penelitian ini selesai dengan baik.

\section{DAFTAR PUSTAKA}

[1] Arikunto. 2010. Penelitian Tindakan Kelas. Jakarta: Bumi Aksara.

[2] Faizah, Umi. 2015. Penerapan Pendekatan Saintifik Melalui Model Project Based Learning Untuk Meningkatkan Ketrampilan Proses Dan Hasil Belajar Siswa Kelas IV SD Negeri Seworan, Wonosegoro. Scholaria, Vol. 5, No. 1 (24-38).

[3] Malawati, Ratna. 2016. Peningkatan Keterampilan Proses Sains Mahasiswa Dengan Model Project Based Learning Berbasis Pelatihan Dalam Pembelajaran Fisika. Jurnal Pendidikan Fisika, Vol. 5, No. 1 (58-63).

[5] Mulyasa, E. 2009. Praktik Penelitian Tindakan Kelas. Bandung: PT Remaja Rosdakarya.

[6] Nurrohman, Sabar. 2007. Pendekatan Project Based Learning sebagai Upaya Internalisasi Scientific Method bagi Mahasiswa Calon Guru Fisika. Yogyakarta: Universitas Negeri Yogyakarta.

[7] Rumini. 2016. Upaya Peningkatan Hasil Belajar Tema Berbagai Pekerjaan Melalui Model Discovery Learning Siswa Kelas 4 SDN Kutoharjo 01 Pati. Scholaria, Vol. 6, No. $1(19-40)$.

[8] Sudjana, Nana. 2011. Penilaian Hasil Proses Belajar Mengajar. Bandung: Remaja Rosda Karya.

[9] Syah, Muhibbin. 2010. Psikologi Pendidikan Dengan Pendekatan Baru. Bandung: PT Remaja Rosdakarya

[10] Wahyudi \& Kriswandani. (2010). Pengembangan Pembelajaran Matematika SD. Salatiga: Fakultas Keguruan dan Ilmu Pendidikan - UKSW.

[11] Warsono dan Hariyanto. 2013. Pembelajaran Aktif Teori Dan Asesmen. Bandung: Remaja Rosda Karya. 
PROFIL PENULIS UTAMA

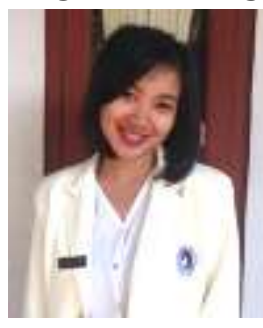

Penulis bernama lengkap "Dyah Kartika Sari”. Lahir di Desa Ngraji

Kecamatan Purwodadi Kabupaten Grobogan Jawa Tengah pada tanggal 12 Agustus 1996 dari pasangan Supiyo dan Sri Sudarwati. Pendidikan sekolah dasar dari SD Negeri 2 Ngraji pada tahun 2002 - 2008. Setelah itu melanjutkan pendidikan sekolah menengah di SMP N 3 Purwodadi pada tahun 2008 - 2011 dan terakhir di SMA N 1 Purwodadi pada tahun 2011 - 2014. Kemudian penulis melanjutkan studi ke perguruan tinggi di Program Studi Pendidikan Guru Sekolah Dasar FKIP UKSW Salatiga pada tahun 2014. Untuk kritik, saran maupun halhal yang berkaitan dengan kelanjutan atau pengembangan dari hasil penelitian ini bisa dikirim ke email penulis: 292014115@student.uksw.edu. 